\title{
Knowledge valley theory
}

\section{Robert B. Mellor}

School of Computing and Information Systems, Kingston University, KT1 2EE, London

E-mail: R.Mellor@kingston.ac.uk

\begin{abstract}
The service sector is characterised by being over-proportionally based on SMEs where these SMEs rarely possess formal intellectual property (IPR) in the sense of patents, etc. Organisations compete intensively and reap relatively short-term Schumpeterian profits by means of incremental innovation. In this high-churn environment, managing internal knowledge networks for 'mutual inspiration' can give rise to significant competitive advantages; however estimates as to how to lever and encourage knowledge assets, and how large benefits are, are very vague. A 3D quantitative fold is presented called Knowledge Valley that allows for a novel knowledge-based theory of the evolution of SMEs and the growth of their knowledge assets. By using concrete values of employee number and annual turnover the model allows largely quantitative estimations of potential knowledge value in organisations and is furthermore amenable to Monte Carlo modelling, which explains from a knowledge assets viewpoint why the management crises in growing SMEs occur.
\end{abstract}

Keywords: innovation; SME; knowledge-based development; knowledge assets; growth potential; theory; modelling.

Reference to this paper should be made as follows: Mellor, R.B. (2014) 'Knowledge valley theory', Int. J. Knowledge-Based Development, Vol. 5, No. 1, pp.5-16.

Biographical notes: Robert B. Mellor holds earned doctorates in various academic disciplines including innovation, computing and biology and is author of over 120 scientific publications in reputable journals, including, e.g., Nature. In addition to his scientific publications, he has written ten books, including four on innovation and entrepreneurship and three of his books have appeared in foreign translations. He has won a number of international prizes for his works, is an active consultant with 12 years industrial experience and is expert advisor to several national governments and the European Union. He now works in Computing, Information Systems and Mathematics at Kingston University, London.

This paper is a revised and expanded version of a paper entitled 'Knowledge Valley Theory explains the growth of SMEs' presented at the Second Edition of the MSKE Conference, Universidade Lusiada de Famalicão, Portugal, July 2011. 


\section{Introduction}

SMEs are well known as the drivers of employment. For example, Gregory (2003) reported that in the 20 years up to 1983 , SMEs created more that $78 \%$ of all net new jobs in Canada and that small businesses (fewer than 50 employees) alone account for $42.5 \%$ (6.7 million jobs) of total Canadian employment. Today, many of these new small firms are involved in IT, internet and e-commerce. Increasingly their competitive advantage is driven by differentiation, their ability to provide unique and superior value in terms of quality, services, and special features or after sales service etc (Porter, 1990). However there is no simplistic answer to the process of development in small companies, and Smallbone and co-authors (1995) pointed out "development is much more a process of slow incremental iterative adaptation to emerging situations..." Indeed one of the hot questions in small business research is how 'mice' may apparently randomly quickly turn into 'gazelles'. The answer may lie in their ability (or chance) to shift from using creative knowledge or innovation in the starting phase, to levering knowledge assets to provide continued innovation to fuel their growth. This is particularly relevant in the light of Hannon and Athertons (1998) findings that there is "no clear consensus that plans and planning, particularly as a formal activity, have a positive impact on small firm's performance". In the context of innovation, Ricardian (scarcity) rents may reflect difficulty in expanding competencies. This is the case where e.g. knowledge underpins a competitive advantage. One example is that in the years 1994 to 1999 knowledge of the internet and its function was a scarce resource, and thus companies in possession of this knowledge asset had a Ricardian advantage, whilst those without, were at a disadvantage (Porter, 2001). This means that knowledge assets, innovation and flexibility were the main factors in any companies' ability to e.g. develop a functioning internet sales channel (i.e., Ricardian and Schumpeterian factors can work together). In the SME segment additional income can traditionally be attributed to Schumpeterian (entrepreneurial) factors because imitation does not occur instantaneously. This is because SMEs typically do not have resources to constantly monitor their competitors, so innovations spread by e.g. the rotation or replacement of staff within a branch, and is hindered by the general difficulty in imitating knowledge assets. Thus there is a period of temporary excess returns when the innovating SME may develop products and or business routines (knowledge assets) but competitors eventually imitate these (Meade, 1984). The SME area has a reputation for being a chaotic area, with many bankruptcies amongst underfinanced companies in a highly Darwinistic environment. In general SMEs have:

- $\quad$ high mortality rates

- $\quad$ equity/debt ratio and costly access to sources of finance

- weak market orientation due to lack of specialised expertise

- low productivity leading to high unit labour costs.

Mortality rates are often measured as VAT de-registrations: Certainly in most EU countries there are not great differences in these figures for SMEs, at the most $20 \%$, between new VAT registrations and VAT de-registrations. This is often taken as meaning a large churn in the SME population across Europe. However a VAT deregistration may 
not at mean a business failure, for example business takeovers (where the company being sold deregisters) are a success, as are various other scenarios; the owner reaching retirement age and selling, the owner having achieved another target and going into voluntary liquidation, are success stories, but are often mistakenly classified as failures

Michael Porter introduced the concept that growth needs 'relentless innovation' (see Porter and Martin 2000), and that the type of innovation powering a growing SME shifts from creative innovation (perhaps supported by small amounts of invention) to innovation powered by incremental 'inspiration'. This shift may sometimes occur in parallel to the shift from product innovation to process innovation as described by Utterback (1994). This shift can already be visible at a company size of 50-100 employees (Mellor, 2005). Thus the type of management needed, shifts character and new management ideas and styles are needed. Jennings and Beaver (1997) found that management processes in small companies "bear little or no resemblance to management processes found in larger firms" and the Confederation of British Industry (CBI, 1995) highlights that companies who do not have the correct management expertise and who do not build a strong management structure, fail to achieve their targets and growth. This has led to many laudable efforts in introducing SME owners to management education, but still Storey and Westhead (1997) remark that there is "little evidence that management training programmes ... led to better performance amongst SMEs", which may indicate that insufficient emphasis is being put on leadership, including the management of knowledge assets and pathways, including the deployment of 'knowledge hunters' (those who go within the organisation ask questions and uncover latent ideas and potential) and 'knowledge gatherers' (those who are aware of need and fill the knowledge gaps from internal and external sources) perhaps combined with the deployment of change agents.

There have been attempts to model the spread of innovations, the most noticeable being that of Rogers (2003) 'diffusion of Innovations' model. However in the intervening years much progress in the use of mathematical modelling has been made. The idea of a 3D model landscape is not new; In the NK model Kauffman (1993) uses ideas of a 'fitness landscape' in evolutionary biology, moving agents across a 'fitness valleys' to higher 'fitness peaks'. At higher points in the landscape, survival is more likely and the risk of extinction reduced. In his model Kauffman extends the NK fitness landscape to coupled landscapes in which a move by one species deforms the fitness of other linked species in the ecosystem, i.e., the species co-evolve. This type of modelling has also more recently become popular with business analysts applying it to anything from situated learning theory (Yuan and McKelvey, 2004) to manufacturing strategies (McCarthy, 2008).

Knowledge management in this sector is particularly important because SMEs rarely possess formal intellectual property (IPR) in the sense of patents etc, but they rather compete intensively and reap short-term Schumpeterian profits by means of incremental innovation. In this high-churn environment managing internal knowledge networks for employee 'mutual inspiration' can give rise to significant albeit transient competitive advantage (Mellor, 2011).

This contribution thus documents an attempt that was made to construct a $3 \mathrm{D}$ model landscape reflecting a knowledge-based view of SME evolution, using quantitative axes including number of employees, annual turnover and branch-specific benchmarked innovation practice (Mellor, 2011). 


\section{Results}

In order to emulate the 'ties' model of Granovetter (1973) a peer-to-peer model was constructed where people in an organisation are represented as nodes (the number of people is represented by the number P), and they are joined by ties. The number of links or ties between nodes is called the diversity innovation (DI) number because it represents the concept of diverseness between the ideas, background and education of the two people. As the DI number increases the potential for innovation and 'mutual inspiration' increases. In this first simple model, the main assumptions are that:

1 a person can have a very large number of ties and that there is no upper limit

2 all ties are exactly similar and have the same 'weight', quality and importance independent of their length

3 each person (employee) has a direct and relatively immediate relationship to the short term overall financial performance of the organisation.

The above assumptions are clearly more relevant to SMEs than larger organisations because:

While individuals clearly have a saturation limit for the number of social ties they can enter into, at least an SME environment will be small enough not to completely overload them. By the same token the informal environments of SMEs, both vertically and horizontally, will tend to equalise the strength of ties; even though Granovetter (1973) shows that weak ties are disproportionally more important. Finally SMEs are more 'lean' in that few employees will not be involved in making or directly supporting mercantile activities. This is certainly more so in SME environments than in large companies where highly salaried staff like strategists or research scientists will be responsible for significant pools of outlay that will not be returnable in the short term (e.g., annual) accounts.

When two individuals enter into a communicative relationship, then a communication pathway (sometimes called a link or 'tie') opens, i.e., in KVT terms, the DI number reaches 1 . As long as the number of people involved is larger than 3 , then the number of pathways is related to the number of people involved and this relationship can be expressed by a simple equation (note that $*$ is the mathematical symbol for multiply):

Figure 1 (a) The DI equation with one large department (b) The DI equation for two departments, D1 and D2, where pd1 represents the number of employees in department D1 and PD2 the number of employees in department 2

$$
\mathrm{DI}=\mathrm{P} * \frac{[\mathrm{P}-1]}{-----}
$$

(a)

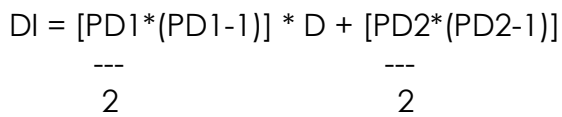

(b) 
Thus the DI number is not the amount of knowledge in an organisation and not the amount of innovation - it merely represents the potential for the type of small-scale, incremental innovations that are thought of as being important in small companies. Using the equation from Figure 1 the amount of potential DI in an organisation as it grows and acquires more employees can be seen in Figure 2.

Figure 2 Growth of DI with number of employees from 0 to 250 (see online version for colours)

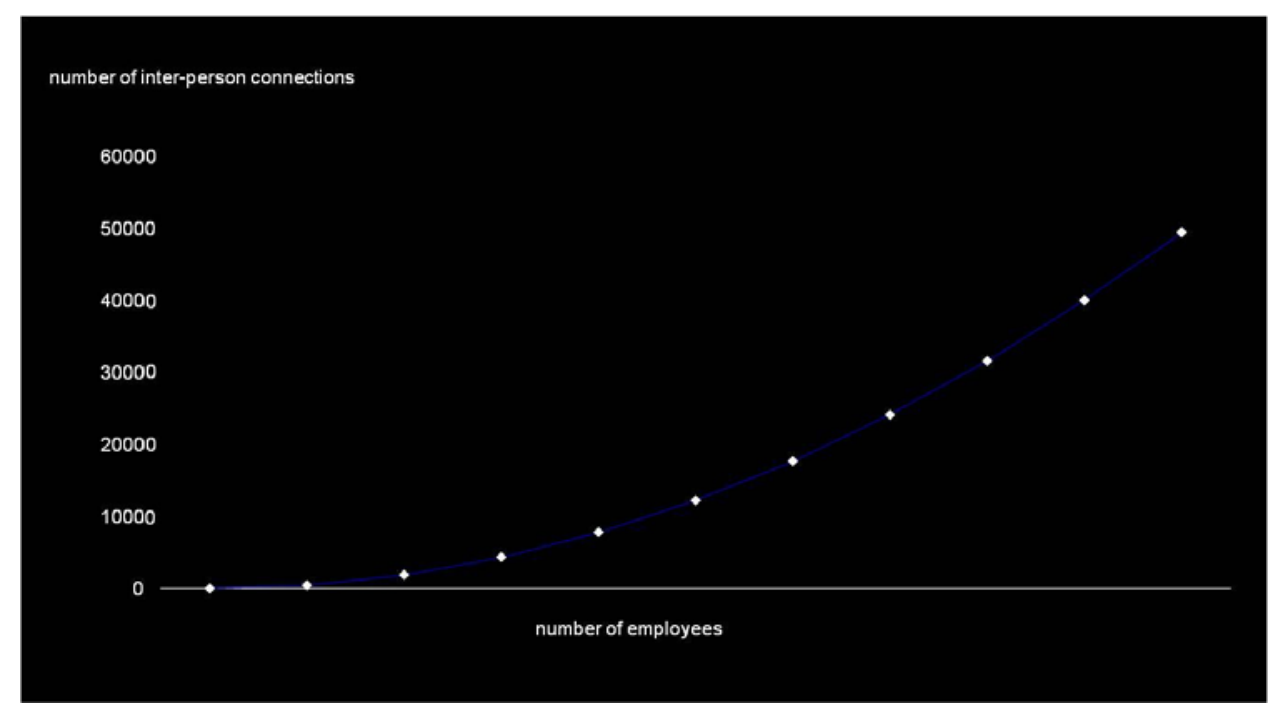

Figure 3 DI number (subjected to a smoothing algorithm) in a population between 1 and 250 nodes (employees), splitting the organisation into equally-sized parts when each dept reaches size 60 (see online version for colours)

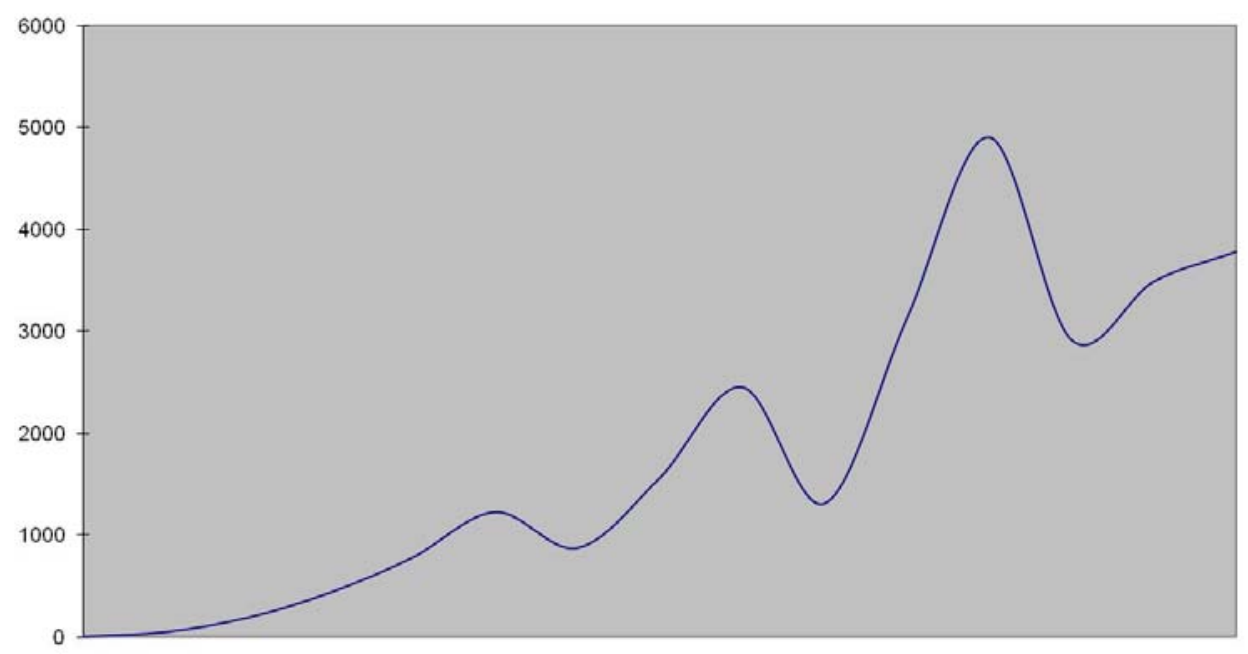

Note: Please note that this model assumes that knowledge transmission through information gatekeepers (nominally heads of the departments) functions perfectly. 
However rampant knowledge sharing, and consequent recombination of knowledge, the fine polishing of processes through organisational learning, etc, into useful innovation, is prevented by the increasing transaction costs for communication: From the DI equation we can see that in a company with a little over 100 employees, it would take approximately 600 hours or 16 man-weeks of working time just for the employees to talk to each other for 5 minutes, excluding that any employees got a chance to repeat any conversations or indeed to do any work. Imagine the effect of this on SME financial performance. Each further employee hired would take around 10 man-hours to talk to existing employees for 5 minutes each. Thus at around 50 employees, transaction costs will simply force all organisations, including SMEs, into a policy of departmentalisation. Unfortunately, as shown in equation in Figure 1B, the effect of forming departments is to decimate the DI number (as shown in Figure 3).

Figure 3 shows the effect of bilateral fission of departments on the DI number as the organisation grows from 1 to 249 employees. The curve has been subjected to a smoothing algorithm because mutual contact between separated individuals will be retained for some time, although this will fade, as well as being diluted by new arrivals and staff turnover. That apart, it should be also noted that other possibilities exist, namely the uneven splitting of the workforce. Table 1 shows the effect on the DI number of taking an organisation of 60 employees (an organisation of 60 employees having a theoretical DI number of 1770) and forming

a six departments of 10

b three departments of 20

c an unequal split of 50 and 10.

Clearly, when the transaction costs of communication become so large as to precipitate dividing the organisation on departmental lines, then those interested in retaining a DI number that is as high as possible will simply split the company into two uneven departments and feed new employees in the smaller part, or at least split the organisation into as few as possible departments.

Table 1 The effects on DI number of splitting a company of 60 employees into departments of different sizes

\begin{tabular}{lccc}
\hline & Six depts. of 10 & Three depts. of 20 & One dept. of 50 and 1 of 10 \\
\hline DI number & 275 & 572 & 1,271 \\
\hline
\end{tabular}

Having established some key values on the $\mathrm{X}$ axis (employee number) and $\mathrm{Y}$-axis (financial performance, as in one of several possible linked indicators like average employee salary or annual financial returns like turnover), the units on the Z-axis can be established. At first this looks unlikely, because there are simply no units for innovation ('kiloinnos' etc), however a $1-100 \%$ scale can be used where the value is the amount derived from the maximum $(100 \%)$ possible using for an organisation of known size from the DI equation.

The third dimension of the model is given by a J-curve or 'hockey stick' curve, because the J-curve represents a transition where - put simply - things get worse before they get better. Imagine a farmer who saves up for a more powerful combine harvester; whilst saving, his standard of living (available cash) drops until such time as the purchase can be accomplished, whereupon increased efficiency will drive his standard of living up 
again, to a level presumably higher than the original level. Many examples of this "it gets worse before it gets better" effect are known from several disciplines, e.g. medicine, the investment in a new venture and this type of curve is also widely used in economics to describe, e.g., devaluation (or depreciation) due to low price elasticity following changes in international exchange rates (i.e., a transient worsening in the national balance of payments due to inelastic demand for imports and exports). In the KVT model values on the $\mathrm{Z}$-axis are derived from business process reengineering (BPR) literature. This means that an organisation that can be benchmarked against others in the same industry sector as having a very small degree of openness to innovation could undergo a theoretical BPR process and after initially decreasing in value (sallies, turnover, profit or other metric) progress along the BPR 'hockey stick' curve up to a level of profitability that is higher than at the origin. At this point the benchmarked degree of openness to innovation will also have increased. This is the kind of J-curve recently used by Bremmer (2006) to describe the stability and standard of living of nation-states (on the y-axis) with 'degree of openness' (on the x-axis). Bremmer used the J-curve not only to illustrate differences in national government, but interestingly, to encourage the concept of manageable change before the country in question breaks apart.

Estimating the position of organisations on the $\mathrm{z}$-axis is semi-quantitative because values of zero and $100 \%$ will hardly be possible. However practitioners can semi-quantitatively measure the actual DI number in an organisation and compare it with the theoretical figure from the equations given in Figure 1; i.e., a measured DI of 100 plus/minus 20 in an organisation possessing a theoretical DI number of 200 is $50 \%$ plus/minus $10 \%$.

At the lowest point on the hockey stick curve the value of a commercial company undergoing BPR may be decreased by $40 \%$. This means that an organisation worth 10 million per annum (or whatever other financial metric is being used) will be down to 6 million. This is the practical value seen and reported by BPR professionals, e.g., McKinsey, Accenture, Deloitte and others, but obviously it does not represent the lowest possible value, because there is nothing to stop the company worth 10 million from going down to zero, or even minus 10 million, it is just that if the value drops below the $40 \%$ rule of thumb, then the firm will probably not survive the BPR operation (Mellor, 2011).

Similarly we can estimate the difference in height of the starting and finishing points; always subject to the difficulties in measuring innovation value as mentioned above. Taking a traditional company as starting point and transforming it, a successful BPR project will, at maturity, approximately triple the value of an organisation (noting that exact figures are not possible to, e.g., the nature of accounting practices, inflation and that the world will have moved on). Higher values than this - reaching up to 10 - have been reported by, e.g., Lillrank and Holopainen (1998), but these are regarded in the industry as being very special cases and are much trickier to compare as they often pertain to newer companies, i.e., comparing internet-based companies like Amazon with a purely theoretical non-internet baseline. The values used in constructing the Knowledge Valley hockey stick curve are given in Table 2.

Table 2, where percent use of innovation plotted against financials (either age, or profit or turnover), results in the hockey stick curve shown in Figure 4. This curve also represents the expected curve of a BPR operation taking a low-innovation organisation from the left to a higher state on the right, high-value organisations on the right of the curve shown in Figure 4 representing those exhibiting a higher degree of openness to 
innovation and thus being better able to use Schumpeterian innovation to create more and/or superior value.

Table 2 An overview of the data used in preparing Figure 4 and Figure 5

\begin{tabular}{lcccc}
\hline $\begin{array}{l}\text { Percent use of } \\
\text { innovation }\end{array}$ & Average wage & $\begin{array}{c}\text { Profit per } \\
\text { employee }\end{array}$ & $\begin{array}{c}\text { Income per } \\
\text { worker }\end{array}$ & $\begin{array}{c}\text { Minimum annual } \\
\text { turnover }\end{array}$ \\
\hline 0 & 20,000 & 13,014 & 33,014 & $8,253,500$ \\
10 & 20,000 & 11,447 & 31,447 & $7,861,750$ \\
20 & 20,000 & 9,640 & 29,640 & $7,410,000$ \\
30 & 18,000 & 8,194 & 26,194 & $6,548,500$ \\
40 & 19,000 & 7,240 & 26,240 & $6,560,000$ \\
50 & 20,000 & 9,399 & 29,399 & $7,349,750$ \\
60 & 21,000 & 14,460 & 35,460 & $8,865,000$ \\
70 & 25,000 & 20,485 & 45,485 & $11,371,250$ \\
80 & 30,000 & 26,510 & 56,510 & $14,127,500$ \\
90 & 35,000 & 33,740 & 68,740 & $17,185,000$ \\
100 & 40,000 & 40,006 & 80,006 & $20,001,500$ \\
\hline
\end{tabular}

Note: Financial values in British pounds as of 2008.

Figure 4 The j-curve as derived from Table 2

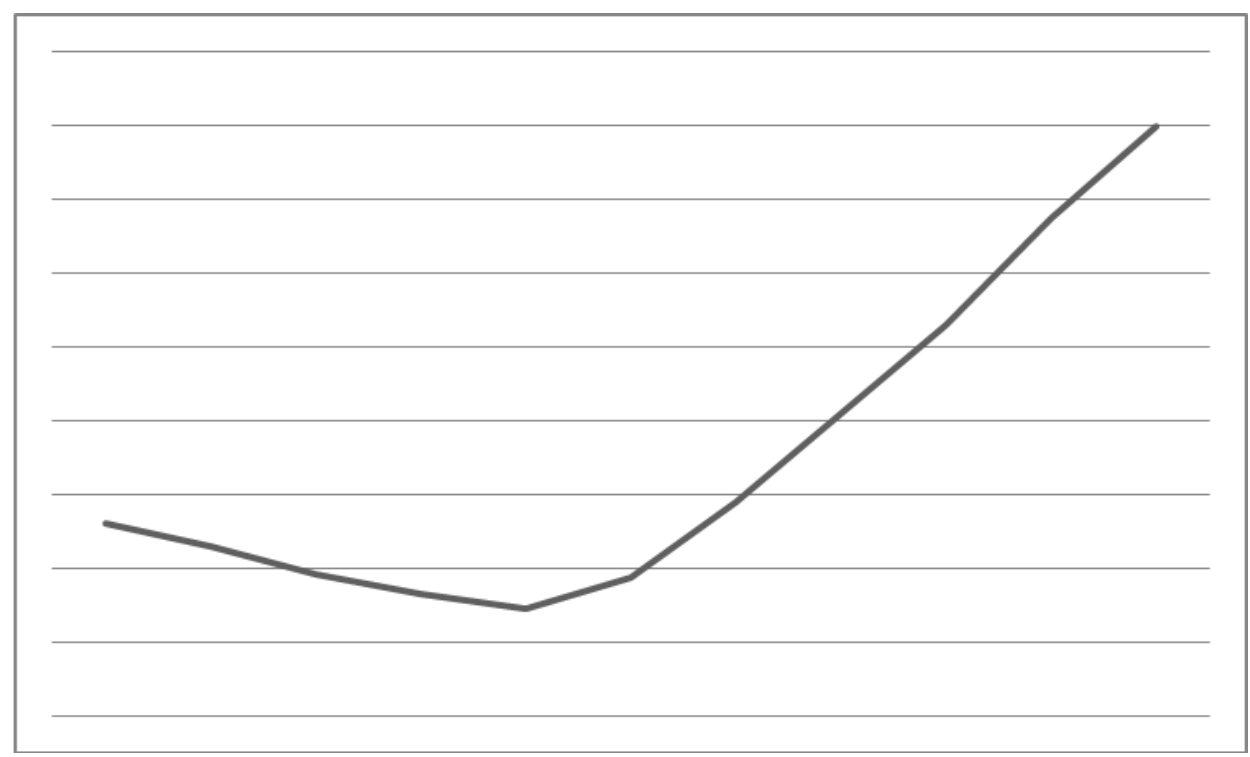

In order to create the $3 \mathrm{D}$ fold called Knowledge Valley, the curve shown in Figure 3 representing increase in DI number with increase in employee number and increase in number of departments is combined with the hockey stick curve represented in Figure 4. Using Maple software this results in the 3D fold shown in Figure 5. 
Figure 5 The fold of knowledge valley, made up of Figure 3 and a BPR J-curve of Figure 4 (see online version for colours)

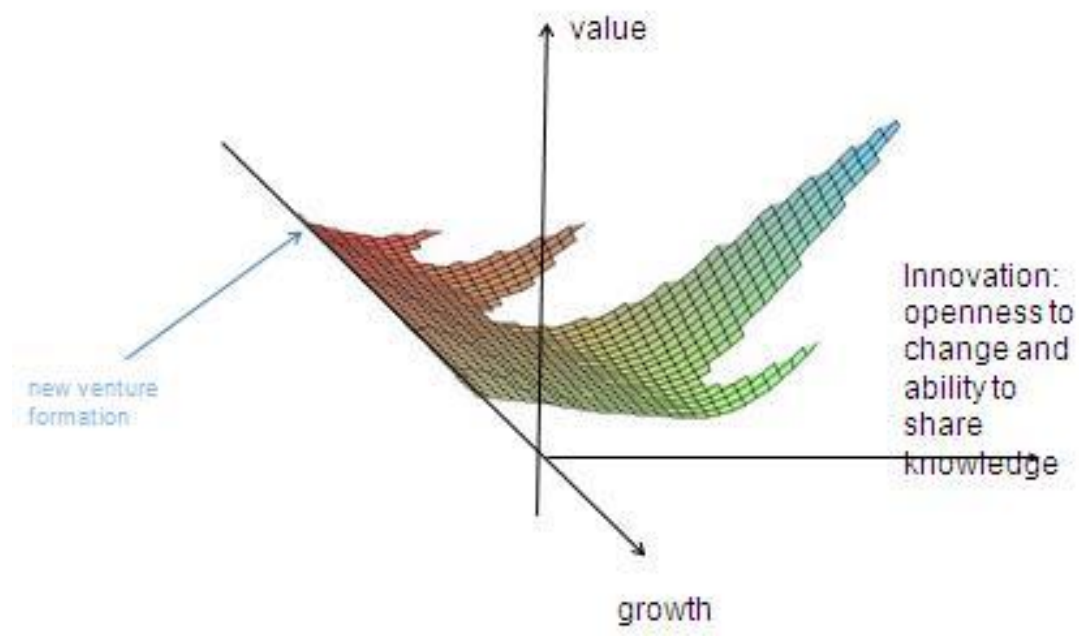

Figure 5 shows the growth of an organisation from new venture formation to size 249 employees (i.e., the border $f$ being an SME under the conventional definition). Figure 5 also shows that during this time the value of the organisation increases concomitantly with employee number and can be measured by several interrelated metrics. Using this fold it can be seen that the first round of departmentalisation - assuming equal fission - cuts deeply into profitability. Practitioners may use this as an argument to divide the workforce unevenly in order to conserve DI number (see Table 1). Figure 5 shows also that the second round of departmentalisation (again, assuming equal fission) cuts very deeply into profitability and indeed endangers the very life of the organisation. In this situation organisations making 30\% viability (measured in the metrics being used, e.g., mark up, profit, dividends, salary floatation etc) will be knocked into the red (i.e., negative) by $10 \%$ or more. KVT implies that this is indeed the most dangerous stage in the growth of an SME.

\section{Discussion}

Clearly almost all companies start small and of these, some grow larger. Models of small business development describe a hypothetical trajectory for the evolution of an SME through its lifetime; however their developmental trajectories will be relatively unique. Most new ventures fail. Those that survive will clearly have some kind of viable mercantile activity plus the ability to successfully persist and perhaps even grow, in a rapidly changing marketplace.

There are several developmental models of company growth; the most often cited are Greiner (1972) and Churchill and Lewis (1983), as well as Garnsey (1996). These and others are adequately reviewed in the standard literature (e.g., Kirby, 2003; Mellor, 2003). The static stage/age model of small business development as presented by Greiner (1972) describes five stages of relatively calm 'evolution' where the transition to the subsequent stage is characterised by a chaotic 'revolution'. Greiner's stages are: 
Table 3 The Greiner (1972) model stages as applied to growth-oriented companies

\begin{tabular}{|c|c|c|c|}
\hline $\begin{array}{l}\text { Greiner } \\
\text { stage }\end{array}$ & $\begin{array}{l}\text { Characteristics of the } \\
\text { evolutionary stage }\end{array}$ & $\begin{array}{l}\text { Followed by } \\
\text { revolution }\end{array}$ & \\
\hline 1 & Creativity & Crisis of leadership & $\begin{array}{l}\text { Moving from purely entrepreneurial } \\
\text { drive to leadership that has different } \\
\text { specialist knowledge }\end{array}$ \\
\hline 2 & Direction & Crisis of autonomy & $\begin{array}{l}\text { Line staff needs to decide between } \\
\text { procedures and initiative. }\end{array}$ \\
\hline 3 & Delegation & Crisis of control & $\begin{array}{l}\text { Lower and middle managers are } \\
\text { perceived to have excess power and } \\
\text { there is little cross-talk between } \\
\text { divisions }\end{array}$ \\
\hline 4 & Coordination & Crisis of red tape & $\begin{array}{l}\text { Senior management has adopted a } \\
\text { watchdog approach }\end{array}$ \\
\hline 5 & Collaboration & $\begin{array}{l}\text { Crisis of } \\
\text { psychological } \\
\text { saturation }\end{array}$ & $\begin{array}{l}\text { Shift to interpersonal collaboration to } \\
\text { get employees to work together } \\
\text { through a sense of mission or purpose. }\end{array}$ \\
\hline
\end{tabular}

Notes: Please note that if success at crisis stage 5 (i.e. renewal) is not chosen then further options include divestment or break-up into a group of smaller enterprises. Please note furthermore that by stage 4 or 5 the organisation may be larger than an SME.

The weakness with the Greiner (1972) and other models is that it correlates the developmental age (in terms of place in the cycle) of a company with its size, but unfortunately it does not specify any units. Furthermore Greiner (1972) does not take knowledge flow and redundancy into account, which should be created by overlapping information sources, business activities and managerial responsibilities combined with learning, indeed Nonaka (1991) argues that redundancy is critical because it encourages higher levels of dialogue and communication, thus ensuring the exchange of tacit knowledge. This may reflect the 'low productivity' found in SMEs. However in fact this parallels the comments of Burns and Whitehouse (2005) about innovation in corporations "Innovation requires organisational 'slack' or 'space' a looseness in resource availability which allows employees to 'borrow' expertise...".

Thus by using the predictions implicit in knowledge valley theory (KVT), one can for the first time provisionally calibrate the Greiner (1972) model: From Figure 5 we can see that the first crisis point comes with the first fission into departments. At this time a typical scenario may be that the organisation has become the size to start incurring significant transaction costs for communication, thus taxing the original entrepreneur excessively such that more leadership is brought in. This corresponds well with Greiner description "Moving from purely entrepreneurial drive, to leadership that has different specialist knowledge" (Greiner, 1972) although the majority of SMEs, not being growth oriented, may suffice with bringing in trusted friends or family. Indeed several studies including the adoption of IT innovation in European SMEs (Mellor, 2005), studies of SMEs in the aerospace industry (McLean and Mellor, 2006) and of 400 SMEs in various trades in South West London (Barnes et al., 2007) all point to the trust factor being over-proportionally more important in small companies as opposed to large corporations.

However as the company grows to maturity beyond the 50+ employees stage the structure will inevitably become more hierarchical and ossified, possibly strangling the leverage of knowledge assets. So again, it may seem like a period of calm when the 
enterprise is growing over 60-70 employees, however Figure 5 shows that the next round of departmentalisation may cut the value of the company right back to the bottom of the J-curve. Thus companies aiming to follow a high-risk, high-gain strategy should be equipped for a potentially disastrous transition at around size 90-110 employees. At this time the new middle management needs to be more professional than may be found in family members, even the losses indicated in Figure 5 assume that knowledge transmission through information gatekeepers (nominally heads of the departments) functions perfectly, certainly imperfect information gate-keeping can be expected to make the situation worse. Clearly at size 110-250 employees the stage "lower and middle managers are perceived to have excess power and there is little cross-talk between divisions" (Greiner, 1972) appears to reflect the large strain being placed on information gatekeepers as implied by the KVT model (see Figure 5).

\section{Conclusions}

The 3D fold called Knowledge Valley presents a novel knowledge-based view of SME development by using calibrated axes of qualitative values, resulting in a 3D landscape representing the innovation potential in an organisation. This is not stockpiled knowledge but rather the potential for the recombination of ideas, for learning and for 'mutual inspiration' within an organisation for entrepreneurial ends. Gratifyingly, this theory, called KVT, appears not only to match classical models of small business development but also is able to explain the classical views of SME development - as obtained by actual field studies - from a new perspective; that of knowledge mapping and knowledge management.

The significant step with KVT is that by attaching concrete values to growth stages, KVT may have many practical uses. It can be used as a map for practitioners and SME owners to navigate their way, whether they wish to chart a course for calm waters, for improved performance and growth, or indeed should they, like many SME owners, do not wish to progress further, these strategies are referred to as 'capped growth' or similar (for a convenient review, see McMahon, 1998) and may simply reflect that the owners lifestyle is satisfied, or a reluctance on part of the owner to take on external investors to finance further growth, or other factors.

\section{References}

Barnes, D., Dyerson, R., Harindranath, G., Dickson, K., Harris, L., Clear, F. and Wallin, P. (2007) Abandoned Heroes: ICT Adoption and Use in SMEs, KURIR-2007-W1 [online] http://kurir.kingston.ac.uk/AbandonedHeroes.pdf (accessed 09.07.2013).

Bremmer, I. (2006) The J Curve, Simon and Schuster, New York.

Burns, P. and Whitehouse, O. (1995) Financing in Europe 2, 3 i Enterprise Centre, Milton Keynes.

CBI (1995) Managing to Grow, CBI, London.

Churchill, N. and Lewis, V. (1983) 'The five stages of small business growth', Harvard Small Business Review, May/June, Vol. 61, pp.30-50.

Garnsey, E. (1996) 'A new theory of the growth of the firm', ICSB 41st World Conference, p.4, Stockholm.

Granovetter, M. (1973) 'The strength of weak ties', American Journal of Sociology, Vol. 78, pp.1360-1380. 
Gregory, M. (2003) 'SME job engine drives Canadian employment growth', Small Business Research, Vol. 3, pp.1-6 [online] http://www.bmo.com/economic/special/sbr3.pdf (accessed 09.07.2013).

Greiner, L. (1972) 'Evolution and revolution as organisations grow', Harvard Business Review, July/August, Vol. 50, pp.37-46.

Hannon, P.D. and Atherton, A. (1998) 'Small firm success and the art of orienteering, the value of plans, planning and strategic awareness in the competitive small firm', Journal of Small Business and Enterprise Development, Vol. 5, pp.102-119.

Jennings, P. and Beaver, G. (1997) 'The performance and competitive advantage of small firms, a management perspective', International Small Business Journal, Vol. 15, pp.66-75.

Kauffman, S. (1993) The Origins of Order: Self-Organization and Selection in Evolution, Oxford University Press, Oxford.

Kirby, D.A. (2003) Entrepreneurship, McGraw-Hill, Maidenhead.

Lillrank, P and Holopainen, S. (1998) 'Reengineering for business option value', Journal of Organizational Change Management, Vol. 11, pp.246-259.

McCarthy, I.P. (2008) 'Manufacturing fitness and NK models', in Frizelle, G. and Richards, H. (Eds.): Tackling Industrial Complexity, Institute for Manufacturing, Cambridge, UK [online] http://http://www.ifm.eng.cam.ac.uk/mcn/proceedings.htm (accessed January 2008.

McLean, J.E. and Mellor, R.B. (2006) The Identification of XML-Related Skills Gaps in the Aerospace \& Defence Industry in the West Focus Region, KURIR-2006-W1 [online] http://kurir.kingston.ac.uk/Report_XML_skill_shortage.pdf (accessed 09.07.2013).

McMahon, R.G.P. (1998) Stage Models of SME Growth Reconsidered, Flinders Business School, School of Commerce Research Paper Series [online] http://commerce.flinders.edu.au/researchpapers/98-5.htm (accessed 09.07.2013).

Meade, N. (1984) 'The use of growth curves in forecasting market development, a review and appraisal', Journal of Forecasting, Vol. 3, pp.429-451.

Mellor, R.B. (2003) Innovation Management, Globe, Copenhagen.

Mellor, R.B. (2005) Sources and Spread of Innovation in Small E-Commerce Companies, Globe, Copenhagen.

Mellor, R.B. (2011) Knowledge Management and Information Systems: Strategy for Growing Organizations, Palgrave.

Nonaka, I. (1991) 'The knowledge-creating company', Harvard Business Review, November-December, Vol. 69, p.97-104.

Porter, M.E. (1990) The Competitive Advantage of Nations, MacMillan, London.

Porter, M.E. (2001) 'Strategy and the internet', Harvard Business Review, Vol. 79, No. 3, pp.62-79.

Porter, M.E. and Martin, R.L. (2000) Canadian Competitiveness; Nine Years after the Crossroads [online] http://www.tcinetwork.org/media/asset_publics/resources/000/000/815/original/Canada_reportMartin_Porter.pdf (accessed 09.07.2013).

Rogers, E.M. (2003) Diffusion of Innovations, 5th revised ed., Simon \& Schuster International, New York.

Smallbone, D., Leigh, R. and North, D. (1995) 'Growth and development in the small firm', International Small Business Journal, Vol. 1, pp.44-62.

Storey, D.J. and Westhead, P. (1997) Management Training and Small Firm Performance, Warwick University SME Center, Coventry, Working Paper 18.

Utterback, J.M. (1994) Mastering the Dynamics of Innovation, Harvard Business School Press, Harvard.

Yuan, Y. and Mckelvey, B. (2004) 'Situated learning theory: adding rate and complexity effects via Kauffman's NK model', Nonlinear Dynamics, Psychology, and Life Sciences, Vol. 8, pp.65-102. 